\title{
Hermeneutics in the Eye of Al Ghazali
}

Mohd Akil Muhamed Ali1

Abur Hamdi Usman²

Muhd Najib Abdul Kadir ${ }^{1}$

Arif Nazri ${ }^{1}$

\section{Mohd Faizulamri ${ }^{1}$}

\author{
${ }^{1}$ Faculty of Islamic Studies, The National University of Malaysia, Malaysia \\ ${ }^{2}$ Department of Usuluddin with Multimedia, International Islamic University College Selangor, Malaysia \\ Corresponding Author Email: aburhamdiusman@yahoo.com
}

Doi:10.5901/mjss.2015.v6n4s2p39

\section{Abstract}

There has been an overwhelming worldwide consensus among scholars that Al Ghazali was blessed with a great mind. Through an examination of the writing of Al Ghazali, this paper attempts to study his theory and method of interpretation, analysed within socio-political and historical context that tended to inform the development of his thought in the light of hermeneutics and modern approaches to the Qur'an. This study found that the Qur'anic hermeneutics methodology has built by Al Ghazali as one of his efforts in projecting the role and value of Qur'an to the Muslim community in order to put the Qur'an as the supreme source of knowledge and truth.

Keywords: Hermeneutics, Al Ghazali, Qur'anic text, Interpretation.

\section{Introduction}

In recent years there is increasing interest in hermeneutics to conduct the interpretive research in the field of exegeses or scriptural interpretation. The tradition of scriptural interpretation had been well-established in the religious discourse as a result of the efforts of each religious believer to better understand to the respective scriptures. In ancient Greek history, hermeneutics considered as a medium used to understand the literary books and religious texts. As flourish development, the Jews also use it in order interpreted Old Testament. The main influence for many hermeneutists is Husserl, a Jewishturned-Christian philosophy born in Moravia in the 19th century. Husserl, known as the "father" of phenomenology defines phenomenology as "a kind of descriptive psychology and an epistemological, foundational eidetic discipline to study essences" (Rutt, 2006). Later also followed by a Christian theologian and seeks how to empower hermeneutic in Biblical studies discourses.

In the Christian tradition discourse of hermeneutics found the momentum and growing from theological phase to rationalization phase and philosophical studies. Then the study developed by Friedrich Schleiermacher (d. 1834), hermeneutics becomes nuanced study of the theoretical philosophy used to understand a variety of texts from diverse forms. Hermeneutic philosophy in this way attempts to foster understanding, as opposed to describing cause and effect when attempting to make sense of and comprehend worldly phenomena (Bauman, 1978)

In Islamic discourses, several modern Muslim scientists such as Fazlur Rahman (d. 1988), Mohammed Arkoun (d. 2010), Nasr Hamid Abu Zayd (d. 2010), etc starting to get an appreciation to the hermeneutics study to see some elements that can be used from the theory of hermeneutics. The emergence of scientists was instrumental in transforming the study of the Qur'anic hermeneutics studies. Through them that the Islamic world began to recognize the tradition of Biblical interpretation from the experts hermeneutics such as Friedrich Schleiermacher, Wilhelm Dilthey (d. 1911), Paul Ricoeur (d. 2005), and Gadamer (2002).

However, many researchers still facing the problem of debate and contradict on how to applied hermeneutics in the social sciences field especially in Islamic exegeses regarding the validity of hermeneutics as a means of interpretation. This paper seeks to describe and analyse the foundation of the validity of hermeneutics as interpretation of media texts of 
the Qur'an. This paper investigates acts of reading and interpretation under scope of the hermeneutics theory. The origins of this thought are traced in classical Western literature. In this case the mechanics of hermeneutics application in Qur'an, as well as the idea of a hermeneutic circle, would be explored with reference to the Al Ghazali's works in his several seminal books. This paper therefore adopts qualitative description and draws Al Ghazali's thinking of Qur'anic Interpretation methodology. The paper has been organized in the following way, section two presented on the origin of hermeneutic. Followed by Al Ghazali on Hermeneutics in section three and the last section is Conclusion.

\section{The Origin of Hermeneutics}

The hermeneutics term originally from hermënuetikós (Greek language) bears obviously to Hermes as reference, the messenger god of the ancient Greeks. In this sense Hermeneutics philosophy historically reaching back at least as far as ancient Greece. Generally the noun is translated "interpretation" or "explanation", "Hermeneutics" means the theory of interpretation, i.e. the theory on how to understanding the texts, utterances, and etc. (it does not mean a certain twentieth-century philosophical movement). However, new approach was brought to apply on it in the modern era for interpreting the Bible from the Church to individual Christians in general, in the wake of the Reformation with its displacement of responsibility. This new focus occurred especially in Germany (Dilthey, 1996).

A seminal figure in the development of modern hermeneutics in Germany was Johann August Ernesti (d. 1781). Ernesti's Institutio Interpretis Novi Testamenti [Instruction for the Interpreter of the New Testament] of 1761 constitutes an important transition from a hermeneutics focused exclusively on the Bible towards a more general hermeneutics. Particularly, Ernesti was quoted by Dilthey (1996) takes five vitally steps how to interpret trough hermeneutics as following:

- The Bible like any other text must be interpreted in just the same way. Ernesti does not follow this principle fully or consistently - for, while he does indeed forgo any reliance on a divine inspiration of the interpreter, Ernesti assumes that, the Bible is the word of God hence must be true and self-consistent throughout, which is not something that he would assume in connection with profane texts. However, Johann Gottfried Herder (d. 1803) and Schleiermacher embrace this principle in a full and consistent way.

- In many cases there are two obstacles that facing by interpretation: (i) different languages possess markedly different conceptual resources. (ii) A particular author's concepts significantly often diverge from his background language.

- The meaning of words very influenced by linguistic usage, so fundamentally the interpretation is a matter of determining the linguistic usage of words.

- In opposition to a tradition of exclusively text-focused reading of the Bible must deploy a detailed knowledge of a text's historical, geographical, etc. context.

- On the forms of holism: when the parts of a text must interpreted as the whole text; and both of these in light of an author's broader corpus and other related texts. In order to acquire sufficient evidence to be able to pin down word usages, and hence meanings such holism particularly necessary.

Further, these five principles refer to Foster (2012) taken over and developed subsequently by his successors such as Herder, Friedrich Ast (d. 1841), and Schleiermacher.

In term of the grammatical interpretation method, the comprehension of the words and common language is required because involves the understanding of the texts. In relation to the sentences the words must be examine by the interpreter carefully, as well as the sentences in the contexts of the paragraphs, until the interpreter can reach an understanding of the text accurately. This gives rise to what Schleiermacher called as the 'hermeneutical circle':

"We cannot understand the meaning of the whole text apart from understanding the meaning of the individual sentences, and even words, in the text. On the other hand, we cannot properly understand the individual parts apart from some grasp of the whole." (Stiver, 1996)

In modern era, according to Palmer (1969) there are six model of hermeneutics usage (based on the progress that has been passed and represents the times and forms of hermeneutics itself) as:

\subsection{Biblical exegesis}

Commonly and widely, understanding of hermeneutics is still referring to the principles of Biblical interpretation. We may discover this understanding if we can look at to the books published in the $17^{\text {th }}$ century, that the meaning of Bible is still 
about scriptural interpretation. In this sense, Dannhauer (d. 1666) book in 1654 "hermeneutica sacra sive Methodus exponemdarum sacrarum litterarum" considered as representative of this perception. After publication of this book, hermeneutic then growing rapidly, especially in the area of German. While in England and America the word "hermeneutics" following the general trends of the interpretation of the Bible. Relatively, Hermeneutics is a new term in English, as are its equivalents in other languages. The earliest citation of this term in the English-language occurred in the Oxford English Dictionary (1961, rpt. 1983) in year 1737 with the meaning, "to be free to the scriptures", when two centuries after its invention, possession of human consciousness in the West was taking definitively, as Kernan (1987) in his Printing Technology, Letters, has so well shown, as well as Samuel Johnson may not using the other methods than hermeneutics.

\subsection{Philological Methodology}

In the $18^{\text {th }}$ century classical philology developed concurrently with rationalism developed. When it come to the historicalcritical method in theology both are major influence to hermeneutics. This method confirmed that the interpretation of the Bible by using a hermeneutic discipline were also applicable to read all other texts (Palmer, 1969). In these developments, the methods of Biblical hermeneutics essentially become synonymous with the theory of secular interpretation of classical philology. At least from the Enlightenment to the present method of Biblical interpretation cannot be separated with philology (non-religious texts).

\subsection{The Science of Linguistic}

In this term, Schleiermacher seeks to re-modify hermeneutics into a science or an art of understanding. He devoted all his intellectual energy to this purpose and managed up to certain limits. He tried to go beyond theology is hermeneutical perspective philological hermeneutics seeks to bring systematic invitation-coherent as a science that describe the conditions of understanding in all dialogs.

\subsection{The Methodological Foundation for the Human Sciences}

Schleiermacher hermeneutics seeks to re-modify it into a science or art of understanding. He devoted all his intellectual energy to this purpose and managed up to certain limits. He tried to go beyond theology is hermeneutical perspective philological hermeneutics seeks to bring systematic invitation-coherent. That is a science that describes the conditions of understanding in all dialogs.

\subsection{The Phenomenology of Being and existential understanding}

In addressing the issue of ontological, Martin Heidegger borrowed methods, Edmund Husserl, and use this phenomenology study on how everyday human existence in the world. Hermeneutics in this context does not refer to science or interpretation method, but the explanation of its phenomenology about human existence itself. Haidegger analysis indicates that the understanding and interpretation of human existence as the basic model.

\subsection{A System of Interpretation (of Symbols)}

Paul Ricoeur defines hermeneutics which refers back to the textual interpretation as a crucial element in hermeneutics. He says, "We mean the theory of hermeneutics is the rules that organize an interpretation". In other words, an interpretation of a particular text or set of potential sign of something that is considered a text.

In another place, as Coyne (1995) has compiled there are many contemporary perspectives to Hermeneutics as table below: 
Table 1. Contemporary perspective on hermeneutics

\begin{tabular}{lll}
\hline Perspective & Main Theme & Proponents \\
\hline Conservative & $\begin{array}{l}\text { To uncover the original meanings of the action-text as } \\
\text { intended by the author, Objective, a-historical, and a- }\end{array}$ & Emilio Betti (d. 1968). \\
& $\begin{array}{l}\text { contextual purposeful meanings would be secured from the } \\
\text { correct and decidable interpretation. }\end{array}$ & \\
Pragmatic (Constructivist) & Historical contexts of the interpreter and interpreted meaning & Hans-Georg Gadamer (d. \\
& that interpretation involves the interpretative norms of a & 2002), and Ludwig \\
Critical & Community & Wittgenstein (d. 1951). \\
& $\begin{array}{l}\text { The emancipatory is a purpose of interpretation; hence in } \\
\text { order to address potential power asymmetries conventional } \\
\text { Radical (Deconstructionist) }\end{array}$ & $\begin{array}{l}\text { Habermas. } \\
\text { wisdoms of community are challenged. }\end{array}$ \\
& $\begin{array}{l}\text { To reveal and conceal knowledge through the play of } \\
\text { difference and contradiction, the texts and social action }\end{array}$ & Jacques Derrida (d. 2004). \\
treated as an endless play of signs. & \\
\hline
\end{tabular}

\section{Al Ghazali on Hermenetiucs}

There have been more and more theorists in the field of interpretation as thought and practice under the title of "hermeneutics", such as Martin Heidegger (d. 1976), Edmund Husserl (d. 1938), Dilthey, and Ricoeur, but in bringing hermeneutical inquiry onto a general level, Schleiermacher (1977) was the most significant responsible.

However in Islamic discourses, hermeneutics as one of interpretation method of al Qur'an is still debatable between Islamic scholars. This debate arises from cultivating Islamic schools within a Western context are not yet viewed as a philosophical field where the relation between theory and practice can be further explored. By moving from text, to tradition, to (public) reason, conservatives scholars according to Barlas (2006) has set up dominant readings of the Qur'an as well as their own interpretive authority without heeding the critiques directed at them and without opening up text, tradition, or reason to critique themselves, as following figure:

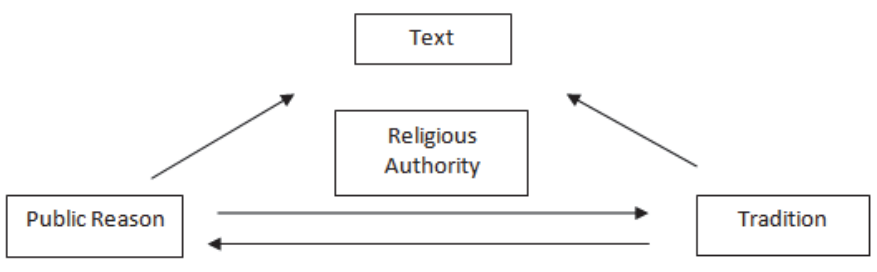

Figure 1. Conservative scholars on Qur'anic interpretation

Hence, in an attempt to partially fulfil the intentions of the title of essay and, in particularly we try to describing the Al Ghazali's thought of hermeneutics refer to his theological and philosophical competency to contribute to the debates related to religion and rationalization regarding interpretation and jurisprudence. As Inglis (2003) believes that Al Ghazali should more accurately be called a champion of the philosophical method than levelled him as an enemy of philosophy.

\subsection{Outline of the life of al Ghazali (d. 1111)}

Abd al-Ghafir al-Farisi's (written in 1113) and Al Ghazali's own autobiography (written in 1108) are two main primary sources often expounded to the biography of Al Ghazali. The former was about 13 years younger than him and was known as his fellow student and teaching assistant. Al Farisi's writing was based on several of his interviews with Al Ghazali and others reportages. Even there is slight inaccuracy in his account. However, al-Ghafir's writing is the one that stands out the most among the classical biography written on Al Ghazali according to Griffel (2004).

Abu Hamid Muhammad ibn Muhammad ibn Muhammad ibn Ta'us Ahmad al-Tusi al-Shafi'i, generally known simply by his nisbah al Ghazali was born in 450/1058 at Tabaran, one of the the district of Tus in northeast of Iran around 1058 AD, now in ruins in the neighbourhood of modern Meshed in Khurasan. His father died and left two sons and daughters in poverty. Having his own dream to raise his sons to be Sufis, he confided his Sufi friend to take 
care of Muhammad and Ahmad. Both then stayed with him and received their education from Imam Ahmad al-Radhkani. There was no date given for the earlier part of his education but as the normal age to school was eleven, one may assume that he was eleven in 1069 (Kraus, 1941).

The life of Al Ghazali mostly examined as the development of his individual personality. Since the 1950s, however, some new attempts appeared to understand his life in its wider political and historical context (Watt, 1963). When his religious confession accepted sincerity, means his thought and work entirely to non-religious factors should be not to reduce carefully. The Al Ghazali's conversion from the life of an orthodox doctor to Sufism may well be was not merely the outcome of his personal development but also a manifestation or transformation of a new stage in the understanding of faith in the historical development of Islam, from the traditional form of faith expressed in the effort to establish the kingdom of God on Earth through the Sharia to a faith expressed as direct communion with God in Sufi mystical experience. This may be a reflection of a development in which the former type of faith had lost its relevance and become a mere formality due to the political and social confusion of the community. During his life Al Ghazali has changed his experiences, and tried to revive the entire structure of the religious sciences on the basis of Sufism, while at the same time arguing for the official recognition of the latter and providing it with solid philosophical foundations.

\subsection{Al Ghazali's Thought of Hermeneutics}

In Islam Qur'anic text is central source and believed is the literal word of God as revealed to the prophet Muhammad and as foundation for all Islamic knowledge, theology, practice and Islamic law. The centrality then put the Muslims already dealing with hermeneutical situations. In this case, the hermeneutical situation has emerged in the early days of the establishment of the Islamic community, especially when the text of the Qur'an has to be explained, translated, and interpreted in order to understand.

One of the thinkers who contributed to the formulation of classical hermeneutics of the Qur'an is Al Ghazali. For Al Ghazali (n.d), Qur'an is the source of truth in many ways and should be viewed from all sides, because it has many dimensions and can be understood through various fields of knowledge. Therefore, Al Ghazali not satisfied with the existing method of interpretation. Most people ignore the artificial meaning of the verses and the sources obtained by naql. Their interpretation is out of control. On the other side, there are those who hold strongly on the artificial meaning and naql, hence the Qur'an appears as static and dogmatic precept. Legal and religious conflict between the two is sticking out, even to the extent of infidel each to another. These conditions led Al Ghazali to criticize the method of interpretation that developed in his time.

His concepts of the Qur'an based on Ash'ari theology and Gnostic Sufism. The first assumption departing from the Ash'arite's conception on Qur'anic text as the "nature" of the essence of god while the later looks the purpose of human existence on earth is to realize happiness in the afterlife. The both not solely formulate a conception of Al Ghazali on the Qur'an, but also describes his thinking project as seen in many of his works to "turn on" religious sciences.

According to Al Ghazali (n.d), Qur'an is a source of truth, from any side the Qur'an seen as the substantial truth. On the other hand, Al Ghazali also emphasizes the essence of the Qur'an as Allah's words (Kalamullah). As Kalamullah, the Qur'an contains the whole meaning of His word, and His Word means his knowledge. Kalamullah is singular; covers the entire meaning of Kalam, as well as His knowledge is singular covers all knowledge and un-separable from His slightest knowledge of what is in the heavens and on the earth.

Based on the messages and the purpose of the Qur'an, Al Ghazali classifies the sciences of the Qur'an into two categories; superficial science and essence science. To clarify this issue, according to Al Ghazali, language is a medium can reveal the outer of the text. The effectiveness of languages ranging from sounds level and ends at the plains semantics. Between them there are several other levels, all these levels forming and categorized as superficial sciences. These sciences that formed as letters and sounds obtained based on the phenomenon of al-Quran in the five branches of science. Makharij al-huruf (phonology); the science that deals with how to read the text, the linguistic of al Qur'an (philology), science that examines words from all its aspects. l'rab al-Qur'an, the science of Qira'at and the last, is the Esoteric Exegesis.

In classifying verses of the Qur'an and its resulted science, Al Ghazali uses metaphorical personification language when he talks superficial and essence sciences. In term of Qur'anic verses Al Ghazali uses Tamtsil (imagery) such kibrit Ahmar (red sulfur), Yaqut, durar (pearl), zabarjud (gemstone), Anbar (perfume), 'ud (eaglewood), tiryaq (antidote), and misk (perfume). All these imageries and conceptions point directly to the essence of the Qur'an while the earthly physical cue is the representative of indirect allegoric and metaphoric.

Refer to Al Ghazali (n.d), the verses of the Qur'an are entitled to such designations than actual objects in nature. In this case, the norm being rests is that the spirit and true meaning of these words are applied to the verses of the Qur'an 
and the science that produces. Here, Al Ghazali interacts with language as a symbol, not as a system of symbols. That is as a set of words that has two dimensions; intrinsic dimension, and outer dimensions or symbol, the meaning of applied language. In this concept, it's not about the nature of the text, because any text can symbolically interpret. Instead, the words can be used refer to the meaning of malakut directly. This is what Al Ghazali did when classifying the verses of Qur'an to the Jawahir, Durar and others.

Al Ghazali departing his Hermeneutic formulations based on the view that ontologically there are two dimension of the nature or structure of the Qur'an: physical and spiritual. Qur'anic text historically was born dimensional orally or in writing in Arabic. Therefore, the essential meaning of the text lies not in the sense of Harf (words), but the inner dimensions of meaning in the beginning. For Al Ghazali, understanding the Qur'an is the ta'wil which is in the Arabic language means returning to the meaning in the beginning.

The structure of hermeneutics in Al Ghazali's thinking described in his Jawahir al-Qur'an (Jewels of the Qur'an), is derived from his scepticism, which, like the Cartesian doubt, leads to a rejection of previous knowledge and hence a rejection of pre-given interpretations of the Qur'an (Kamal, 2004). In his interpretation concepts, the meaning of Qur'anic text is assumed to be objective, which is located in a literal sense. The more literally our understanding of the text, the more closer to the message or revelation of God's will. If we want to understand the meaning of the text out of its literal (harfiyah) meaning, then there must be qarinah or linguistic signs to show it. For example, a shift in the meaning of the mansukh to nasikh, from general to specific, or from mujmal to mufassal there must necessarily linguistic signs (qarinah) that accompanies it. In this case, the interpreter can-not arbitrarily make a shift in understanding the meaning of the text of the Qur'an without the qarinah.

Another rule of Al Ghazali's hermeneutics is the literal meaning of the text is unseparated from the hidden meaning. He says in Jawahir al-Qur'an:

Then, know that the realities we hinted at have secrets and jewels; [but also] they have seashells, and the shell is that which appears first. Some people who reach the seashells know [only] these, while others break the shells and carefully examine the pearls [inside them].

Al Ghazali (1983) also argues against those who rely on the external meanings of the Qur'anic verses. In related to the science of reading is the science of the outward exegesis of the Qur'an. This is the reason why its resemblance with the pearl has because strong so that some people imagine that it is the pearl [it-self] and that beyond it there is nothing more valuable than it. It is with it that most people are content. How great are their deception and deprivation for they have imagined that there is no rank beyond theirs! However, in relation to those who possess the knowledge of [other] sciences of the shell, they are at a rank high and noble, since the science of exegesis is mighty when compared to other sciences of the shell, because it is not meant for them while they are meant for it. In this sense Kamal (2004) has summarized Al Ghazali's hermeneutic position as follows:

- In the beginning the commences with a presupposition should be frees from all pre-given structures, rules and judgments for the understanding of the meaning of the Qur'an.

- It stresses the unity of literal "external" and hidden "internal" meaning of the revealed text.

- To understand the meaning of the text should be relies on mystical intuition. This issue is significant as intuitive experience for obtaining knowledge and apprehending the meaning of the Qur'an, because nothing stands between mind and its object in intuition.

- It encourages emotional atonement to the text.

According to Al Ghazali (1983), the readers of Qur'an in the preliminary stage when reading it must isolate their mind from all extraneous influences, and focus on the text directly and intuitively. This has four functions:

- To free our mind or our understanding from the dogmas of theological schools and from pre-given rules, interpretations and commentaries of the meaning of the Qur'an. Refer to an authority, this is because a theological school might be correct in some place, but also it can be an obstacle to understanding the meaning.

- To reject all outward exegeses and literal meanings of the Qur'an.

- To free our mind from worldly purposes which weaken spiritual strength and from the desire of materiality benefits.

- To free the soul from sin, because sin one of obstacles to understand the meaning of the Qur'an. This is one of the fundamental characteristics of a divine text and its authorship.

The hermeneutics methodology of Al Ghazali in the interpretation of the Qur'an is based on his understanding of the purpose and intent of the Koran and a long journey in search for the ultimate truth. The method of interpretation is one of the efforts of Al Ghazali in projecting the role and value of the Qur'an in the community in order to put the Qur'an as the supreme source of knowledge and truth. Therefore, efforts need to be to involve in its various disciplines, as a 
philosopher, theologian, jurist and Sufi.

Al Ghazali sought to draw on the various methods of evolving into a pattern interpretation. Although he gave the place and emphasize the rational interpretation methods ( $b i$ al-ra'y), he also emphasized the history of interpretation and attention (bi al-ma'tsur). Similarly, even though he was very forward inner side (batin) interpretation, he does not ignore the meaning of the exoteric term (zahir). Al Ghazali integrated various suppression methods in addition to the terms of the interpretation and the principle in attempt to open the dynamic interpretation of the prospective method, in addition to maintaining the authenticity of the value of the Qur'an.

\section{Conclusion}

The Qur'an is believed by Muslim to be a divinely revealed scripture over a period of twenty three years between 610 and 632. The scope of this essay is, however, limited to Al Ghazali's thinking. A serious study of the thought of Al Ghazali would lead to a conclusion that the ideas to turn on the religious sciences reveal significant reform in various aspects. To catch the aspects it, can be traced from the first position in the thinking of Al Ghazali to the methodology of Qur'an interpretation. In this case, Al Ghazali has contributed to discourse Qur'anic studies.

The Qur'an has a very broad dimensional interpretation, Al Ghazali then sought to draw on the various methods that evolved into the methodology of interpretation. The interpretation that can be done from the exoteric dimension (zahir) through bi al-riwayah approach (ma'tsur) and bi al-ra'y (rational) or from the esoteric dimension (batin) through Irfani approach, psychognosis approach and intuition (kashf). As such, Al Ghazali has combined the harmony of exoteric meaning and an esoteric meaning as well as rational interpretation (bi al ra'y) and notice of narration (bi al-ma'tsur). He also tried to understand the Quran from various dimensions according to the characteristics of the paragraphs and letters. Thus, it appears that Al Ghazali was an exegete in the creative synthesis. As the synthesis, Al Ghazali has using and gathering various methods of interpretation of the Qur'an that appear in his time. Al Ghazali's creativity appears in its ability to use and put these methods in proportion and places. However, since the knowledge and experience of Al Ghazali in the Sufism field, the pattern of Sufi (esoteric) is very prominent and became first choice in his methodology.

\section{References}

Al Ghazali, A. H. (1983). The Jewels of the Qur'an. London: Kegan Paul International.

Al Ghazali, A. H. (n.d). Ihya 'Ulum al-Din. Beirut: Dar al-Fikr.

Apel, K. O. (1980). Toward a Transformation of Philosophy. London: Routledge.

Barlas, A. (2006). Qur'anic Hermeneutics and Sexual Politics. Cardozo L. Rev., 28, 143.

Bauman, Z. (1978). Hermeneutics and Social Science: Approaches to Understanding. London: Hutchinson and Son.

Betti, E. (1955). Teoria Generale della Interpretazione. Vol. 1. D. A. Giuffre (Ed.). Milan.

Coyne, R. M. (1995). Designing Information Technology in the Postmodern Age: From Method to Metaphor. Cambridge: The MIT Press.

Derrida, J. (1970). Structure, sign and play in the discourse of the human sciences. In Mackesy, R and Donato, E. (eds). The Structuralist Controversy. Baltimore: Johns Hopkins University Press, pp. 246-72.

Derrida, J. (2013). Of Grammatology. Baltimore: Johns Hopkins University Press.

Dilthey, W. (1996). Hermeneutics and the Study of History. Princeton: Princeton University Press.

Dilthey, W. (1860). Schleiermacher's Hermeneutical System in Relation to Earlier Protestant Hermeneutics. Princeton: Princeton University Press

Gadamer, H. G. (1975). Truth and Method. New York: The Seabury Press.

Griffel, F. (2004). Al Gazali's Concept of Prophecy: The Introduction of Avicennan Psychology into As'arite Theology. Arabic Sciences and Philosophy. Cambridge University Press, Vol. 14 (2004), pp. 101-144.

Habermas, J. (1972). Knowledge and Human Interests. Boston: Beacon Press.

Habermas, J. (1980). The hermeneutic claim to universality. In Bleicher, J. (ed). Contemporary, Hermeneutics: Hermeneutics as Method, Philosophy and Critique. London: Routledge, pp. 181-211.

Hirsch, E. D. (1967). Validity in Interpretation. New Haven: Yale University Press.

Inglis, J. (2003). Medieval Philosophy and the Classical Tradition. In Islam, Judaism and Christianity. London: Routledge.

Kamal, M. (2004). Al-Ghazali's Hermeneutics and Phenomenology. Religion East and West: Journal of the Institute for World Religions, 4, pp. 77-89.

Kernan, A. B. (1987). Printing Technology, Letters, \& Samuel Johnson. New Jersey: Princeton University Press.

Kraus, A. B. (1941). Raghensis Opera Philosophica. Isis. Vol. 33, No. 2, June.

Palmer, R. E. (1969). Hermeneutics; interpretation theory in Schleiermacher, Dilthey, Heidegger, and Gadamer. Illinois: Northwestern University Press.

Rutt, J. (2006). On Hermeneutics. n.p.: E-LOGOS 
Schleiermacher, F. (1977). Hermeneutics: The Handwritten Manuscripts. Missoula: Scholars Press.

Stiver, D. R. (1996). The Philosophy of Religious Language. Oxford: Blackwell Publishers Ltd.

Watt, W. M. (1963). Muslim Intellectual: A Study of al-Ghazali. Edinburgh: Edinburgh University Press.

Wittgenstein, L. (1953). Philosophical Investigations. New York: Macmillan. 